1 2

3

This article was published in Biochemical Engineering Journal, 104, 34-40, 2015 http://dx.doi.org/10.1016/j.bej.2015.05.009

\title{
EFFECT OF OPERATING AND DESIGN PARAMETERS ON THE PERFORMANCE OF A MICROBIAL FUEL CELL WITH LACTOBACILLUS PENTOSUS
}

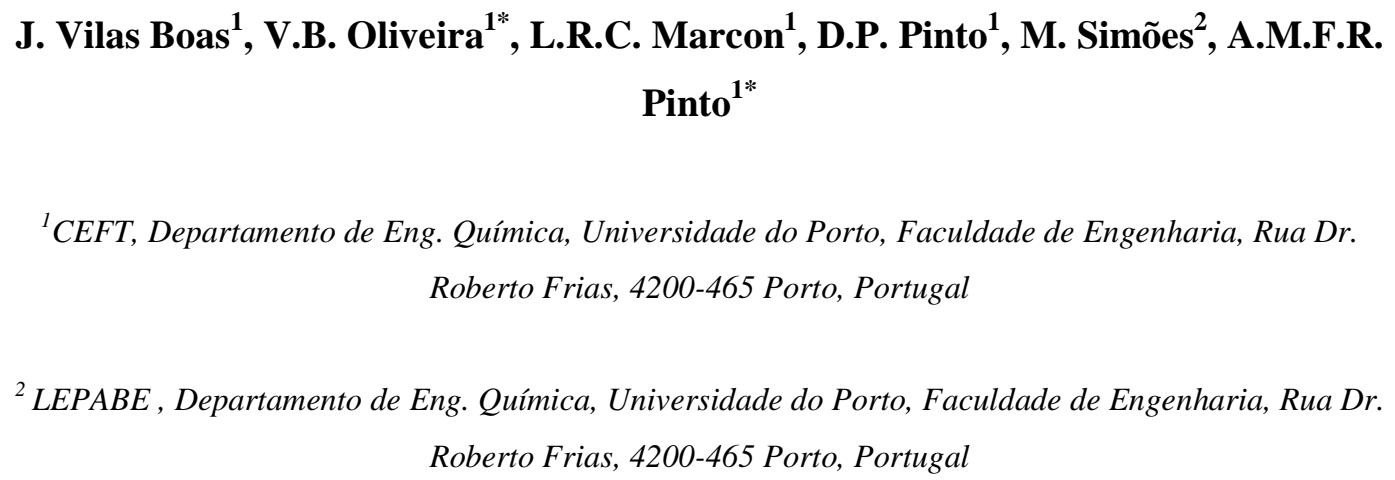

\section{Abstract}

A microbial fuel cell (MFC) is a novel biotechnological system able to simultaneously produce renewable energy and perform wastewater treatment. The aim of this work was to study the effect of configurational parameters, such as membrane area, anode electrode size and cell design and operating conditions, such as flow rate and shear stress on the MFC performance towards its optimization. A synthetic wastewater based on a dairy industry effluent and pure culture of Lactobacillus pentosus was used. For each condition tested, the MFC performance was evaluated in terms of power density, chemical oxygen demand (COD) removal rate and the characteristics of the L. pentosus biofilm attached to the anode electrode (biomass amount, cell viability and total and extracellular proteins and polysaccharides). The maximum power density, $8.09 \pm 1.52$ $\mathrm{mW} \mathrm{m} \mathrm{m}^{-2}$, was achieved with the lower flow rate tested $\left(0.05 \mathrm{~L} \mathrm{~h}^{-1}\right)$. For all the conditions tested the COD removal rates were between $56 \%$ and $61 \%$. The different configurational and operating conditions tested influenced the energy production and the biofilm characteristics. However, the wastewater treatment efficiency was not considerably affected. L. pentosus proved to be capable of treating a dairy wastewater and produce electricity without the presence of a mediator. Further investigation needs to be done to improve the MFC overall performance. 
Keywords: operating conditions, design parameters, microbial fuel cell, power output,

2

3

\section{1. Introduction}

5 Microbial fuel cells (MFCs) emerge as a challenging technology with potential to

6 accomplish simultaneously wastewater treatment and electricity production and some

7 efforts have been made to turn the MFCs into a scalable technology for real applications

8 [1-4]. In the last years, the research on the MFCs technology improved its effectiveness

9 on wastewater treatment $[5,6]$. However, their power output is still lower than the ideal

10 one due to the activation losses which are related to the bacteria metabolism, Ohmic

11 losses due to ionic conductivity limitations and concentration polarization, due to mass

12 transport limitations [1]. Consequently, in order to achieve the power density goals it is necessary to deeply investigate the effect of the operating conditions and the design parameters on the MFC performance [1,7-14].

The hydrodynamic conditions (flow rate and shear stress) are one of the key issues affecting both the biofilm formation and the performance of a MFC [1]. Also, the ability of a MFC to work under different hydrodynamic conditions is an important factor when a MFC is used in a wastewater treatment plant. Studies regarding the effect of the shear stress on the MFC performance and on biofilm formation show that an increase on the shear stress leads to an increase on power output, on the biofilm thickness and on the biomass concentration $[7,8]$. The increase on the biofilm thickness may be due to an increase of the biofilm cohesion as a response to the high detachment forces induced by the higher shear stress and to an increase of the biomass production resulting from higher mass transfer rates. However, if the shear stress is too high, cell detachment prevails and a reduction on power production is observed [8]. Similar findings were described for the effect of the flow rate on the MFC performance. The power output increases with the flow rate until a maximum value after which an increase on flow rate leads to a decrease in power output [9-13]. Also, higher flow rates lead to lower residence times with a consequent decrease on the MFC Coulombic efficiency and COD removal rate [9-12].

Another way to improve the MFC performance is to change the design parameters such as the anode electrode size, the membrane thickness and the reactor layout [14-19]. The reactor design is an important parameter that affects the power production in a MFC and among the different reactor designs proposed by the researchers the most commonly 
used are the single chamber (SCMFC) and double chamber (DCMFC) (cube, cylinder

2

4

5

or rectangular) microbial fuel cells [15-19]. Both designs have an anode and a cathode

(air or liquid) separated by a membrane and one electrode on each side linked by an external circuit. Most of the experimental work performed with MFCs has been made with DCMFC. However, in the last years, there has been considerable attention to SCMFC, since this design has an open air cathode system avoiding the use of a catholyte, shortening the distance between electrodes, which can reduce the MFC internal resistance and allows working the MFC without an artificial aeration on the cathode [17-19].

Having in mind the different challenges regarding the MFCs technology, the aim of this work is to study the effect of different design parameters (membrane area, anode electrode size and cell design) and operating conditions (flow rate and shear stress) on the performance of an in-house developed MFC. A synthetic wastewater simulating an effluent of a dairy industry with Lactobacillus pentosus was used. The MFC performance was critically discussed according to the power density, the COD removal efficiency and the characteristics of the L. pentosus biofilm formed on the anode electrode.

\section{Materials and methods}

\subsection{SCMFC and DCMFC construction}

The DCMFC was constructed with two equal Plexiglas chambers having $1 \mathrm{~L}$ of volume each. The two chambers were separated by a proton exchange membrane (PEM) (Nafion 212, QuinTech, Germany) and a rubber gasket was added to prevent leakage. The anode of the SCMFC was similar to the one used on the DCMFC but in this case the cathode was opened to the air. A Nafion 212 membrane was, also, used to separate the anode and the cathode (Figure 1b). In both designs, the electrodes were connected with a copper wire. A graphite brush with filaments of carbon fibre (Mill-Rose Company, USA) and different sizes (one BP 3/4" and the other BP 1") was used as anode electrode and a plain carbon paper with $100 \mathrm{~cm}^{2}$ (FuelCellsEtc, USA) coated with $1 \mathrm{mg} \mathrm{cm}^{-2}$ of platinum black was used as cathode electrode.

The anodic compartment was filled with $70 \%$ of synthetic dairy wastewater and $30 \%$ of a pure culture of L. pentosus. The anode compartment was sealed with expanded polystyrene to ensure anaerobic conditions. The cathode compartment of the DCMFC 
1 was filled with distilled water and equipped with an air-sparger to operate under aerobic conditions.

$4 \quad$ 2.2. Microorganism and culture conditions

5 L. pentosus CECT 4023 was used to inoculate the anodic compartment of the MFC. $L$. 6 pentosus was incubated for 3 days in MRS (deMan, Rogosa and Sharpe) Broth (Merck, 7 VWR) at $23 \pm 3{ }^{\circ} \mathrm{C}$ and with agitation (120 rpm). Afterwards the inoculum was

8 centrifuged at $3777 \mathrm{~g}$ for $15 \mathrm{~min}$ and resuspended in $300 \mathrm{~mL}$ of synthetic wastewater to 9 a final bacterial concentration of $10^{6}$ colony forming units $\left(\mathrm{CFU} \mathrm{mL}{ }^{-1}\right)$. The bacterial 10 suspension was placed in the anodic compartment and the remaining volume (70\%) was 11 filled with synthetic wastewater.

12 The synthetic wastewater was prepared in order to simulate the average characterization 13 of a dairy industry wastewater and was used as growth medium in the anodic 14 compartment. The synthetic wastewater consisted of glucose $\left(85 \mathrm{mg} \mathrm{L}^{-1}\right)$, yeast extract $15\left(5 \mathrm{mg} \mathrm{L}^{-1}\right)$, milk powder (1300 $\left.\mathrm{mg} \mathrm{L}^{-1}\right)$, starch $\left(5 \mathrm{mg} \mathrm{L}^{-1}\right), \mathrm{NH}_{4} \mathrm{Cl}\left(50 \mathrm{mg} \mathrm{L}^{-1}\right), \mathrm{K}_{2} \mathrm{HPO}_{4}$ $16\left(22 \mathrm{mg} \mathrm{L}^{-1}\right), \mathrm{KH}_{2} \mathrm{PO}_{4}\left(11 \mathrm{mg} \mathrm{L}^{-1}\right), \mathrm{MgSO}_{4} \cdot 7 \mathrm{H}_{2} \mathrm{O}\left(78 \mathrm{mg} \mathrm{L}^{-1}\right)$ and $\mathrm{CaCO}_{3}\left(35 \mathrm{mg} \mathrm{L}^{-1}\right)$.

\section{2.3. MFC operation}

19 The MFC was operated at a constant temperature $\left(20 \pm 1^{\circ} \mathrm{C}\right)$ and continuous mode. The 20 anode chamber was connected to a bottle, with $4 \mathrm{~L}$ of capacity, as the anode groove.

21 The flow rate was controlled by a peristaltic pump and two different flow rates were tested $\left(0.05 \mathrm{~L} \mathrm{~h}^{-1}\right.$ and $\left.0.11 \mathrm{~L} \mathrm{~h}^{-1}\right)$ in order to study the effect of the flow rate on the MFC performance. To evaluate the effect of the hydrodynamic stress on MFC performance, a stirring device (CAT, R50) was used on the anode chamber and two different rotation conditions were tested (Reynolds number of agitation - $\mathrm{Re}_{\mathrm{A}}-0$ and 8397). Assuming that the biological reactor had the behavior of an agitated vessel, the $\operatorname{Re}_{\mathrm{A}}$ as a consequence of each rotation speed tested can be calculated according to the following equation $[13,20]$ :

29

$$
\operatorname{Re}_{A}=D^{2} \times N \times \frac{\rho}{\mu}
$$

30

31

32

where: $\mathrm{D}$ is the cylinder diameter $(\mathrm{m}) ; \mathrm{N}$ is the rotation speed (rps); $\rho$ is the fluid density $\left(\mathrm{Kg} / \mathrm{m}^{3}\right), \mu$ is the fluid viscosity $(\mathrm{Kg} / \mathrm{m} . \mathrm{s})$. 
1 As already mentioned, in order to study the effect of the anode electrode area on the cell

2 performance two different electrode sizes were used (BP1" and BP3/4") and to study

3 the effect of the membrane area, tests were performed with a Nafion 212 membrane 4 with $25 \mathrm{~cm}^{2}$ and with $42.3 \mathrm{~cm}^{2}$ of active area.

5 The tests were conducted during one month, the polarization curves and the COD

6 content measurements were performed once a week and the characterization of the

7 biofilm attached to the anode electrode, was performed at the end of the experiment.

8 Due to the large amount of tests performed and the results obtained, a sub-set of 9 conditions, which reproduce with accuracy the remaining results and follow the same 10 trends, were selected and are presented in the following section. Also, since the biofilm 11 characterization was performed at the end of the experiment ( $4^{\text {th }}$ week of operation), the 12 polarization and power density curves are presented for this week. The COD removal 13 rate and the maximum power density achieved in each test is presented as the average 14 value of the different measurements performed during the MFC operation (each week).

\subsection{Analytical Methods}

\subsubsection{Biomass Quantification}

19 Colony forming units (CFU) were streaked on MRS agar and PCA (Plate Count Agar) 20 plates to determine the viable cells of $L$. pentosus presented in each experiment, in order 21 to ensure a constant value in each experiment and the absence of contamination.

\subsubsection{Extracellular polymeric substances (EPS) extraction}

24 The biofilm attached to the brush was resuspended in $20 \mathrm{~mL}$ of buffer $\left(2 \mathrm{mM} \mathrm{Na}_{3} \mathrm{PO}_{4}, 2\right.$ $25 \mathrm{mM} \mathrm{NaH}_{2} \mathrm{PO}_{4}, 9 \mathrm{mM} \mathrm{NaCl}$ and $1 \mathrm{mM} \mathrm{KCL}$, at a pH of 7) and $2 \mathrm{~g}$ of a cation exchange 26 resin Dowex ${ }^{\circledR}$ Marathon ${ }^{\circledR} \mathrm{C}$ sodium form $\left(\mathrm{Na}^{+}\right.$form, strongly acidic, 20-50 mesh, 27 Sigma-Aldrich, Portugal) was added to performed the EPS extraction at $400 \mathrm{~min}^{-1}$ and 4 $28{ }^{\circ} \mathrm{C}$ for $4 \mathrm{~h}$. Further, the extracellular components (matrix) were separated from the cells 29 (pellet) by centrifugation at $3777 \mathrm{~g}$ for $15 \mathrm{~min}$. This procedure was adopted since it 30 follows the methodologies proposed by Frølund et al. [21] and Simões et al. [22].

\subsubsection{Proteins and polysaccharides quantification}

33 The protein content was quantified using the Lowry Peterson's modified method (Total 34 Protein Kit, Sigma Aldrich, No. TP0300) [23]. Total polysaccharide concentration was 
1 determined by the phenol-sulphuric acid method of Dubois [24]. The final values were

2 presented as mass of proteins or polysaccharide per biofilm dry weight.

3

$4 \quad$ 2.4.4. Biofilm quantification

5 The quantification of the biofilm was made through the total volatile solids (TVS) of the

6 homogenised biofilm suspension, according to the standard method number 2540 (A to

7 D) from Standard Methods [25]. The biofilm mass accumulated for $2 \mathrm{~h}$ at $550 \pm 5^{\circ} \mathrm{C}$ in

8 a furnace was expressed in terms of mass per volume.

9 In order to evaluate the biofilm formed in each test, a new parameter was introduced 10 and estimated in this study, $\alpha$, which quantifies the viability of the cells presented in the

11 biofilm. This parameter expressed in CFU mg-1 is defined as the ratio of the CFUs

$12\left(C_{C F U}\right)$ inoculated in the anode compartment, and the total dry weight of the biofilm 13 attached to the anode electrode $\left(B_{t}\right)$.

$$
\propto=\frac{C_{C F U}}{B_{t}}
$$

15

16 where $C_{C F U}$ is expressed as CFU mL $\mathrm{mL}^{-1}$ and $B_{t}$ as $\mathrm{mg} \mathrm{mL}^{-1}$.

17

18

19

20

21

22 
1 The polarization curves were performed in an electrochemical work station (Zahner -

2 Electric $\mathrm{GmbH} \& \mathrm{CO}$ ) and the test were performed in galvanostatic mode (set the

3 current and measure the cell voltage).

4 The power density was calculated by the following equation:

5

$$
P=U \times \frac{I}{A}
$$

6

7 where $P$ is the power density expressed in $\mathrm{W} \mathrm{m}^{-2}, U$ is the cell voltage $(\mathrm{V}), I$ is the 8 current $(\mathrm{A})$ and $A$ is the membrane active area $\left(\mathrm{m}^{2}\right)$.

9

\section{2.5.2. Internal Resistance}

11 The internal resistance (expressed in $\Omega$ ), $R_{\text {int }}$, was estimated, for all experiments, in the 12 region of the Ohmic losses by measuring the slope of the linear section of the 13 polarization curves (I vs U).

\section{Results and Discussion}

\subsection{Effect of flow rate}

18 To study the effect of the flow rate on the DCMFC performance two different flow rates 19 were tested, $0.05 \mathrm{~L} \mathrm{~h}^{-1}$ and $0.11 \mathrm{~L} \mathrm{~h}^{-1}$. The corresponding polarization and power 20 density curves are presented in Figure 2 and the maximum power density, the COD 21 removal rate and the internal resistance values are shown in Table 1. The values for the 22 different parameters used to characterize the biofilm formed on the anode electrode are, 23 also, presented in Table 1.

24 As can be seen in Figure 2, as the current density increases the differences in 25 performance for the two conditions tested increase. Also, a higher power density and 26 COD removal rate is achieved with a lower flow rate (maximum power density of 8.09 $27 \pm 1.52 \mathrm{~mW} \mathrm{~m}^{-2}$ and COD removal rate $\left.57.36 \pm 11.49 \%\right)$. In fact, higher flow rates lead 28 to lower hydraulic retention times and consequently the time available for 29 microorganisms to metabolize the organic matter is lower $[9,10,13]$. The results indicate 30 that a better performance is achieved after has been given time to microbial community 31 develop, since in these conditions the nutrient capture and the extent of hydrolysis of 32 substrate is more favourable. This decrease in performance for the higher flow rate is, 
1 also, due to a higher internal resistance, since as can be seen the resistance increases

2 from 8,794 to $13,200 \Omega$ for the higher flow rate (Table 1 ). Similar results of $R_{\text {int }}$ and

3 power density were reported by Ieropoulos et al. [12], using the anaerobic bacterium

4 Geobacter sulfurreducens.

5 In this study, the higher flow rate promoted the formation of biofilms with higher total

6 polysaccharides and protein content (Table 1). These polysaccharides were mainly from

7 the extracellular biofilm matrix since $1.17 \mu \mathrm{g} \mathrm{mg}^{-1}$ and $2.46 \mu \mathrm{g} \mathrm{mg}^{-1}$ represent $62 \%$ and

$856 \%$ of the total polysaccharides content, respectively, for the lower and the higher flow

9 rate. Similar results were found concerning the proteins content in biofilm, where the 10 matrix values $\left(5.88 \mu \mathrm{g} \mathrm{mg}^{-1}\right.$ and $\left.5.93 \mu \mathrm{g} \mathrm{mg}^{-1}\right)$ represent $71 \%$ and $64 \%$ of the total 11 proteins (Table 1) for the lower and higher flow rate. Pereira et al. [26], also, reported 12 that higher flow rates promoted the formation of biofilms with higher amounts of 13 extracellular polymeric substances. The existence of more complex matrix increases the 14 biofilm mechanical stability and the resilience to environmental stresses [27,28]. This 15 lead to a denser biofilm attached to the anode surface (Table 1). However, for this 16 condition, the biofilm had a lower cell viability, $5.45 \times 10^{5}$, which may explain the lost 17 on performance for a higher flow rate. These results suggest that most of the 18 constituents of the biofilms formed under the higher flow rate do not account for the 19 MFC efficiency, causing apparent internal resistance to the passage of electrons through 20 the anode electrode and protons towards the anode electrolyte. In fact, transport 21 limitations inside the biofilm restrict the current generation in a MFC [29].

22 These experiments showed that a flow rate of $0.05 \mathrm{~L} \mathrm{~h}^{-1}$ provided a higher performance, 23 a higher wastewater treatment efficiency and allowed the formation of a biofilm with a

24 higher cell viability. Therefore, the next experiments were performed with this flow 25 rate.

\section{3.2. Effect of shear stress}

28 To evaluate the effect of the hydrodynamic stress on the MFC performance two 29 different rotation speeds were tested on the anode chamber. The values of the cell 30 voltage and power density as a function of the current density, for the two Reynolds 31 number of agitation tested ( 0 and 8397), and calculated according to equation (1), are 32 presented in Fig. 3. The values of maximum power density, COD removal, internal 33 resistance and the different parameters used to characterize the biofilm are presented in 34 Table 2. Figure 3 show similar results in polarization and power density curves at lower 
1 current densities but for current densities above $8 \mathrm{~mA} \mathrm{~m} \mathrm{~m}^{-2}$ substantial differences

2 between the two conditions tested occur. The maximum power density was achieved

3 without agitation, $8.09 \pm 1.52 \mathrm{~mW} \mathrm{~m}^{-2}$ (Table 2). This is due to the fact that higher shear

4 stress leads to an increase of the detachment rate of the cells. In these conditions,

5 bacteria on the electrode transfer electrons by other mechanism instead of using only

6 redox mediators, leading to a decrease of the energy production and consequently a

7 decrease of MFC performance [8,13]. Also, the results show that a higher shear stress

8 leads to a denser biofilm and a higher internal resistance. Consequently higher Ohmic

9 losses are presented decreasing the cell power density. However, as can be seen by the

10 COD removal rates presented in Table 2, a higher shear stress conducted to a higher

11 COD removal rate, $61.45 \pm 11.24 \%$. This is due to the fact that hydrodynamic stress

12 leads to a better distribution of the microbial consortia and substrate all over the

13 chamber with a consequently higher metabolic activity and microbial performance.

14 The shear stress lead to a higher total polysaccharides content, $2.87 \mu \mathrm{g} \mathrm{mg}^{-1}$, and a

15 lower total protein content, $4.92 \mu \mathrm{g} \mathrm{mg}^{-1}$ (Table 2). Therefore, the results show that the

16 shear stress changed the biofilm characteristics, increasing biofilm weight and

17 decreasing the cells viability ( $\alpha$ value), the extracellular content in polysaccharides and

18 the total proteins content, which can compromise the cohesion of the biofilm [27]. The

19 results presented by Simões et al. [22] describing the effect of shear stress under laminar

20 and turbulent flows in the phenotypic characteristics on the Pseudomonas fluorescens

21 biofilm, also, showed that higher shear stress contributed to increase the biofilm weight

22 and decrease the content on matrix polysaccharides [22].

\subsection{Effect of membrane area}

25 Two different membrane active areas, $25 \mathrm{~cm}^{2}$ and $42.3 \mathrm{~cm}^{2}$, were used to study this 26 effect on the cell performance. The corresponding polarization and power density 27 curves can be seen in Figure 4 and the comparative values of maximum power density, 28 COD removal rate, internal resistance and the biofilm characteristics are presented in 29 Table 3. Figure 4, show similar open circuit voltage $(\sim 0.73 \mathrm{~V})$ in both cases, however, 30 with the increase of current density a significant drop of voltage in the MFC with the 31 higher membrane area is observed. As a result, the lower membrane area leads to a 32 higher cell performance. It would be expected that an increase on the membrane area 33 will lead to an increase of proton diffusion from the anode, since a higher area is 34 available to protons flow towards the cathode [14]. However, in the present work, an 
1 increase on the membrane area leads to a decrease on power output and an increase on

2 the internal resistance. As can be seen in Table 3, the MFC with the higher membrane

3 area presents an increase in the internal resistance, from $8,794 \Omega$ to $16,190 \Omega$, with a

4 consequent increase on the ohmic losses and a decrease on the cell performance. This is

5 due to the higher biofilm weight observed in this case (Table 3), since a denser biofilm

6 leads to a higher resistance. The internal resistance quantify the facility or difficulty to

7 transfer the electrons and protons from the anode to the cathode side. Therefore a higher

8 internal resistance means a lower flow of electrons and protons towards the cathode

9 side. Consequently the availability of these two species to participate on the oxygen

10 reduction reaction decrease, decreasing the cathode reaction rate and consequently the

11 overall cell performance. Although the power density is higher in the MFC with the

12 lower area, the COD removal rate is slightly higher for the MFC with the higher active

13 area, $59.42 \pm 6.52 \%$ (Table 3 ), suggesting that the ability of the microorganism to treat

14 the wastewater was not affected by the changes on the membrane area. Similar results

15 were found by $\mathrm{Oh}$ et al. [14] when they studied the effect of anode, PEM and cathode

16 surface areas on the DCMFC. They found that the performance decreased when the

17 PEM area was lower than the anode and cathode areas, due the higher internal

18 resistances achieved.

19

20 3.4. Effect of anode electrode size

21 The effect of the anode electrode size on the DCMFC performance was studied using

22 two different electrode sizes: BP1" and BP3/4". Figure 5 presents the polarization and

23 power density curves and Table 4 displays the maximum power density, COD removal

24 and the internal resistance values and the parameters used to characterize the biofilm for

25 each situation. As can be seen in Figure 5, the MFC with the higher electrode (BP1”)

26 demonstrated a better performance achieving higher power outputs and with a

27 maximum power density of $2.58 \pm 0.34 \mathrm{~mW} \mathrm{~m}^{-2}$ (Table 4). The results confirmed that

28 the small ratio between the anode surface area and the anodic compartment reduces the

29 electron transfer and its collection by the anode electrode decreasing the power density

30 [9]. It should be mentioned that the electrode area is one of the important parameters

31 that affect the MFC performance, since it is directly related to the electrons transfer and

32 collection and to the bioelectrochemical reactions that occur on the anode compartment.

33 If the electrode has a lower area, it has a lower bioelectrochimical reaction rate and 
consequently lower electrons production and transfer rate and less bacteria attached to

2 its surface. This will lead to biofilms with lower weight (Table 4) and lower fuel cell

3 performances. In this study, a decrease of the internal resistance was observed with the

4 decrease of the anode electrode area, $14,400 \Omega$ instead of $16,190 \Omega$, mainly due to a

5 reduction of the biofilm weight. These results are in accordance to those proposed by

6 other authors [15]. However, since the maximum power density was achieved with the

7 highest anode electrode size it can be concluded that, in this case, the internal resistance

8 is not the major loss affecting the cell performance.

9 As can be seen in Table 4, the lower electrode was associated with higher COD removal 10 rate $60.63 \pm 7.39 \%$, meaning that the majority of the organic matter presented in the 11 effluent was used by bacteria but do not contribute to electricity generation. This is due 12 to the inability of the electrode to collect all the electrons produced due to a decrease of 13 the electrode surface area. Furthermore, for the MFC with the lower electrode, the 14 extracellular polysaccharides content was lower $\left(0.60 \mu \mathrm{g} \mathrm{mg}^{-1}\right)$ being $46 \%$ of total 15 amount. However, the extracellular content of biofilm proteins was found to be $71 \%$ of 16 the total.

\subsection{Effect of MFC design}

19 The performances of a DCMFC and a SCMFC were compared and the results for the 20 polarization and power density curves are shown in Figure 6. The values obtained for 21 the maximum power density, COD removal rate, internal resistance and the biofilm 22 characteristics are presented in Table 5. As can be seen in Figure 6, the open circuit 23 voltage for the SCMFC is higher $(0.98 \mathrm{~V})$ than the one obtained with a DCMFC, 24 however, an increase on current density drastically decreased the cell voltage and the 25 power density. This behavior indicates the presence of substantial internal resistances 26 for the SC (single chamber) design. In fact, as can be seen in Table 5, the higher internal 27 resistance of this design caused higher Ohmic losses and consequently lower 28 performances. Usually shortening the electrode distance by using a more compact 29 design, like the SC design, conducts to lower internal resistances and higher 30 performances [17-19]. However, this simpler design has the cathode opened to the 31 ambient air, so the oxygen reaches the electrode by natural mechanisms, such as 32 diffusion and natural convection, leading to a lower oxygen transfer rate. In such 33 conditions a lower oxygen concentration is presented on the cathode electrode 34 decreasing the oxygen reduction rate. The results for the COD removal rate were 57.36 
$1 \pm 11.49 \%$ for the DCMFC and $58.40 \pm 3.48 \%$ for the SCMFC, indicating that the 2 SCMFC as a slightly better performance regarding the wastewater treatment.

3 Comparing the biofilm characteristics (Table 5), for the two MFC designs, it was found 4 that the biofilm formed in the SCMFC showed higher weight, $1.60 \mathrm{mg} \mathrm{mL}^{-1}$, but lower

5 cell viability. The biofilm developed in the SCMFC showed higher total polysaccharide 6 content $\left(3.29 \mu \mathrm{g} \mathrm{mg}^{-1}\right)$, however, the extracellular amount, $1.26 \mu \mathrm{g} \mathrm{mg}^{-1}$, was only $38 \%$

7 of the total value. The lower content on matrix components can possibly indicate a

8 decrease of the biofilm cohesion and mass transfer rate with a consequently decrease on

9 the power production [27]. The total protein content in the biofilm of the SCMFC was 10 lower than the one of the DCMFC, however, both were mainly constituted by matrix 11 content $(60 \%$ of total protein in the SCMFC and $71 \%$ of the total protein in the 12 DCMFC) (Table 6). The differences in both biofilms characteristics are not substantial, 13 being for that reason the internal resistance and the cathode design the major factors for 14 the differences in both performances [18].

\section{Conclusions}

17 In this work different operating and design conditions were studied in order to optimize 18 the overall performance (energy production and wastewater treatment capability) of a 19 MFC feed with a dairy wastewater effluent and using L. pentosus. Regarding the effect 20 of the flow rate it was found that a lower flow rate provided higher energy production 21 and wastewater treatment. Promoting shear stress on the anode compartment showed to 22 increase biofilm weight and improve the COD removal rate, but a decrease on the 23 power output was observed. Therefore further work should be performed in order to 24 find the same trend between the energy production and the wastewater treatment. The 25 increase of membrane area brought undesirable effects on power density, mainly due to 26 a significant increase on the cell internal resistance, but a higher COD removal rate was 27 observed. Further studies considering the anode and cathode cross sectional area could 28 be useful to analyze the combined effect of the anodic and cathodic limitations with the 29 membrane area. The anode electrode size also revealed to be an important parameter 30 affecting the MFC performance, since a reduction of its size lead to a lower power 31 density and similar COD removal rates. The DCMFC design provided higher energy 32 production, however, both designs showed effectiveness on wastewater treatment. It can 33 be concluded that the different configuration and operating conditions tested had 34 considerable effects on energy production, being the membrane area and the MFC 
1 design the most critical parameters which affect the MFC performance due to a

2 considerably increase of the cell internal resistance, whereas the efficiency for the

3 wastewater treatment was not significantly affected. The results also shown that $L$.

4 pentosus is capable of developing biofilms at the anode electrode and has potential to

5 simultaneously treat a dairy wastewater and produce energy without the use of

6 mediators.

8 Acknowledgements

9 J. Vilas Boas acknowledges the Master research grant fellowship (SAESCTN10 PIIC\&DT/1/2011 - NORTE-07-0124-FEDER-000026) supported by "Fundo Europeu 11 de Desenvolvimento Regional" (FEDER), inserted in the program "O Novo Norte" 12 (ON.2) and also the national funding of FCT/MEC (PIDDAC). V.B. Oliveira 13 acknowledges the post-doctoral fellowship (SFRH/BDP/91993/2012) supported by the 14 Portuguese "Fundação para a Ciência e Tecnologia" (FCT), POPH/QREN and 15 European Social Fund (ESF). POCI (FEDER) also supported this work via CEFT and 16 LEPABE.

\section{References}

[1] V.B. Oliveira, M. Simões, L.F. Melo, A.M.F.R. Pinto, Overview on the developments of microbial fuel cells, Biochem. Eng. J. 73 (2013) 53-64.

[2] B.E. Logan, Simultaneous wastewater treatment and biological electricity generation, Water Sci. Technol. 52 (2005) 31-37.

[3] P. Aelterman, K. Rabaey, P. Clauwaert, W. Verstraete, Microbial fuel cells for wastewater treatment, Water Sci. Technol. 54 (2006) 9-15.

[4] Z. Du, H. Li, T. Gu, A state of the art review on microbial fuel cells: A promising technology for wastewater treatment and bioenergy, Biotechnol. Adv. 25 (2007) 464-482.

[5] Y. Ahn, B.E. Logan, Domestic wastewater treatment using multi-electrode continuous flow MFCs with a separator electrode assembly design, Appl. Microbiol. Biotechnol. 97 (2013) 409-416.

[6] K.Y. Kim, K.J. Chae, M.J. Choi, E.T. Yang, M.H. Hwang, I.S. Kim, High-quality effluent and electricity production from non-CEM based flow-through type microbial fuel cell, Chem. Eng. J. 218 (2013) 19-23. 
[7] A. Rochex, J.J. Godon, N. Bernet, R. Escudié, Role of shear stress on composition, diversity and dynamics of biofilm bacterial communities, Water Res. 42 (2008) 4915-4922.

[8] H.T. Pham, N. Boon, P. Aelterman, P. Clauwaert, L. De Schamphelaire, P. Van Oostveldt, et al., High shear enrichment improves the performance of the anodophilic microbial consortium in a microbial fuel cell, Microb. Biotechnol. 1 (2008) 487-496.

[9] M. Di Lorenzo, K. Scott, T.P. Curtis, I.M. Head, Effect of increasing anode surface area on the performance of a single chamber microbial fuel cell, Chem. Eng. J. 156 (2010) 40-48.

[10]D. Aaron, C. Tsouris, C.Y. Hamilton, A.P. Borole, Assessment of the effects of flow rate and ionic strength on the performance of an air-cathode microbial fuel cell using electrochemical impedance spectroscopy, Energies 3 (2010) 592-606.

[11]D.F. Juang, P.C. Yang, T.H. Kuo, Effects of flow rate and chemical oxygen demand removal characteristics on power generation performance of microbial fuel cells, Int. J. Environ. Sci. Technol. 9 (2012) 267-280.

[12]I. Ieropoulos, J. Winfield, J. Greenman, Effects of flow-rate, inoculum and time on the internal resistance of microbial fuel cells, Bioresour. Technol. 101 (2010) 3520 3525 .

[13] V. Oliveira, L. Melo, T. Carvalho, A. Pinto, M. Simões, Effects of hydrodynamic stress and feed rate on the performance of a microbial fuel cell, Environ. Eng. Manag. J. (2013) Acepted for publication.

[14]S.E. Oh, B.E. Logan, Proton exchange membrane and electrode surface areas as factors that affect power generation in microbial fuel cells, Appl. Microbiol. Biotechnol. 70 (2006) 162-169.

[15]A. Dewan, H. Beyenal, Z. Lewandowski, Scaling up microbial fuel cells., Environ. Sci. Technol. 42 (2008) 7643-7648.

[16]K. Watanabe, Recent developments in microbial fuel cell technologies for sustainable bioenergy., J. Biosci. Bioeng. 106 (2008) 528-536.

[17] M.H. Osman, a. a. Shah, F.C. Walsh, Recent progress and continuing challenges in bio-fuel cells. Part II: Microbial, Biosens. Bioelectron. 26 (2010) 953-963.

[18]X. Zhang, H. Sun, P. Liang, X. Huang, X. Chen, B.E. Logan, Air-cathode structure optimization in separator-coupled microbial fuel cells, Biosens. Bioelectron. 30 (2011) 267-271. 
[19] S. Cheng, B.E. Logan, Increasing power generation for scaling up single-chamber air cathode microbial fuel cells, Bioresour. Technol. 102 (2011) 4468-4473.

[20]C.J. Geankoplis, (1993), Transport Processes and Unit Operations, 3rd Edition, Prentice-Hall International Inc., New Jersey, 144-145.

[21]B. Frølund, R. Palmgren, K. Keiding, P.H. Nielsen, Extraction of extracellular polymers from activated sludge using a cation exchange resin, Water Res. 30 (1996) 1749-1758.

[22]M. Simões, M.O. Pereira, S. Sillankorva, J. Azeredo, M.J. Vieira, The effect of hydrodynamic conditions on the phenotype of Pseudomonas fluorescens biofilms., Biofouling. 23 (2007) 249-258.

[23] G.L. Peterson, A simplification of the protein assay method of Lowry et al. which is more generally applicable., Anal. Biochem. 83 (1977) 346-356.

[24]M. DuBois, K. a. Gilles, J.K. Hamilton, P. a. Rebers, F. Smith, Colorimetric method for determination of sugars and related substances, Anal. Chem. 28 (1956)

[25]APHA, AWWA, WPCF, Standard Methods for the Examination of Water and Wastewater, American Public Health Association/American Water Works Association/Water Environment Federation, Washington DC, USA, 20th,1998.

[26] M.O. Pereira, M. Kuehn, S. Wuertz, T. Neu, L.F. Melo, Effect of flow regime on the architecture of a Pseudomonas fluorescens biofilm. Biotechnol. Bioeng. 78 (2002) 164-171.

[27]C.C. Goller, T. Romeo, Environmental influences on biofilm development, Curr. Top. Microbiol. Immunol. 322 (2008) 37-66.

[28]C.I. Torres, A.K. Marcus, H.S. Lee, P. Parameswaran, R. Krajmalnik-Brown, B.E. Rittmann, A kinetic perspective on extracellular electron transfer by anoderespiring bacteria, FEMS Microbiol. Rev. 34 (2010) 3-17.

[29] C.I. Torres, A.K. Marcus, B.E. Rittmann, Proton transport inside the biofilm limits electrical current generation by anode-respiring bacteria, Biotechnol. Bioeng. 100 (2008) 872-881. 


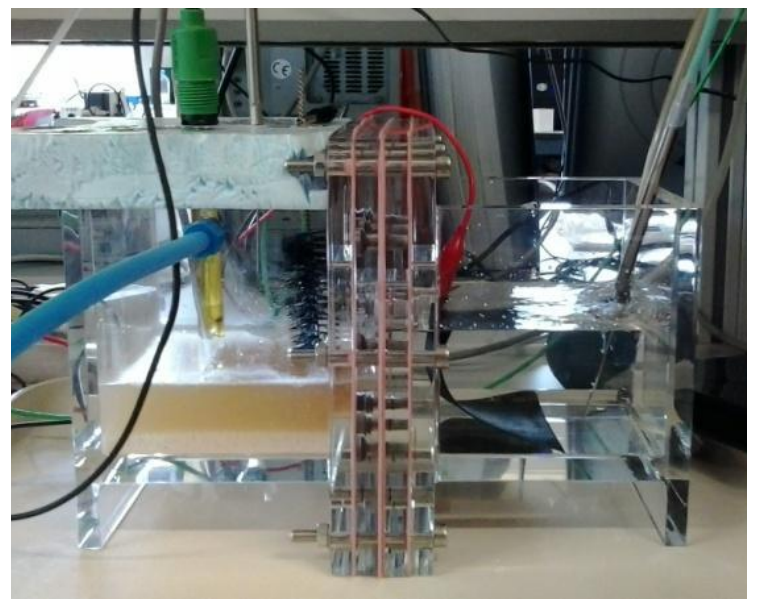

a)

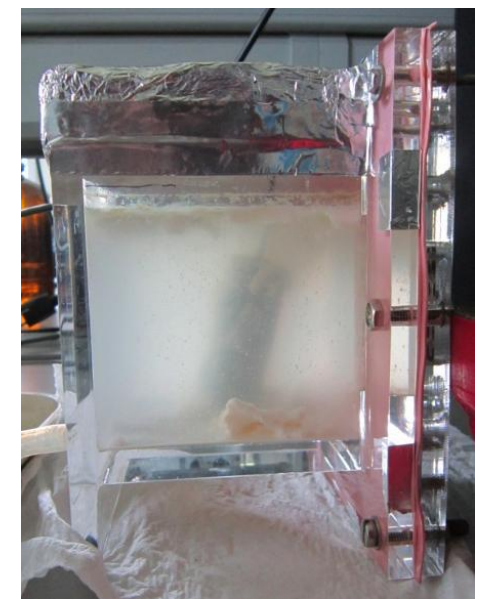

b)

Figure 1 - In-house a) DCMFC and b) SCMFC.

Vilas Boas et al. (2015) 


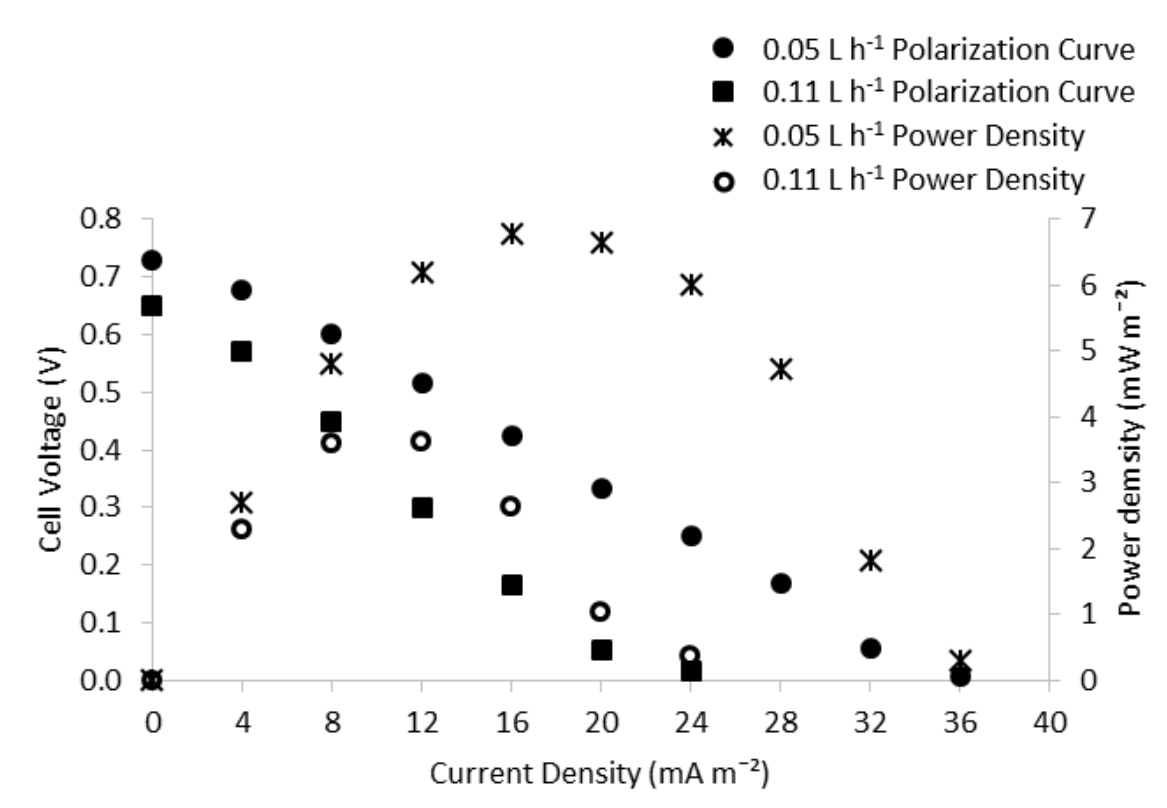

Figure 2 - Polarization and Power Density curves for the two flow rates tested.

Operating conditions: $R e_{A}=0$. Design conditions: DCMFC, $25 \mathrm{~cm}^{2}$ of active area, Nafion 212 and anode electrode BP1".

Vilas Boas et al. (2015) 


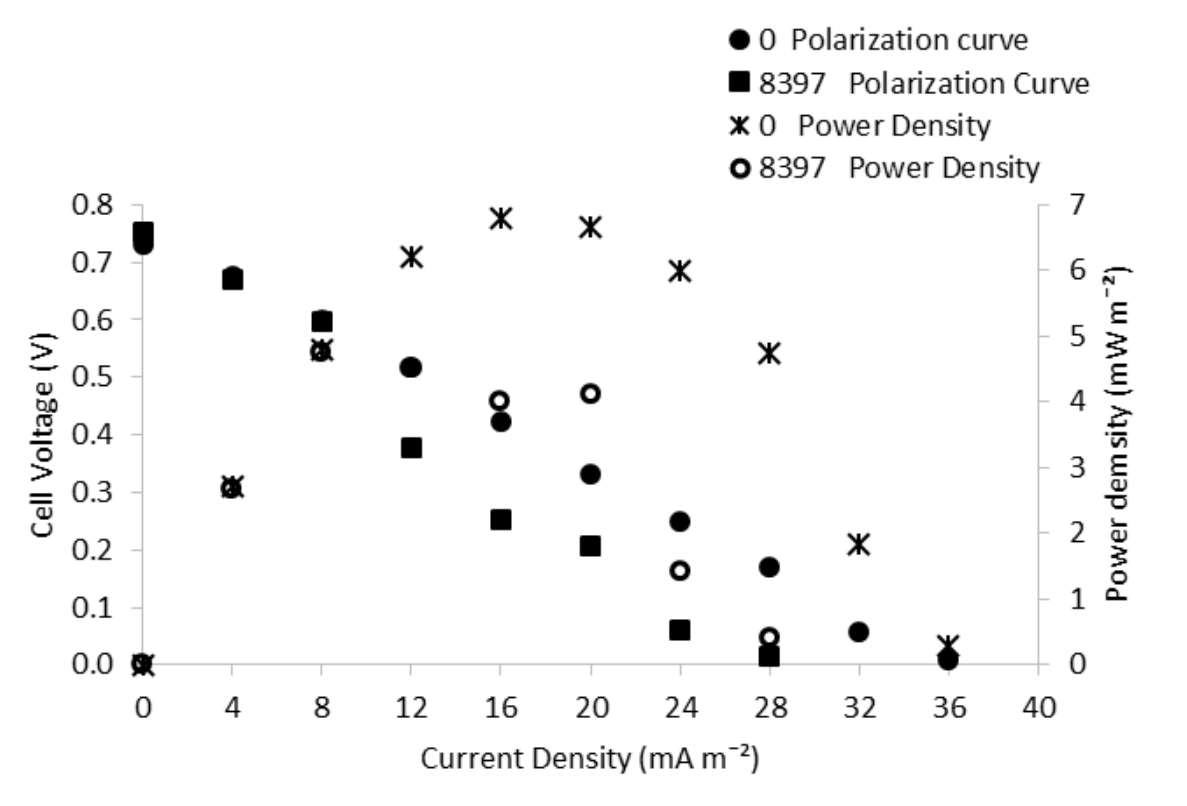

Figure 3 - Polarization and Power Density curves for the two shear stress applied.

Operating conditions: feed rate of $0.05 \mathrm{~L} \mathrm{~h}^{-1}$. Design conditions: DCMFC, $25 \mathrm{~cm}^{2}$ of active area, Nafion 212 and anode electrode BP1".

Vilas Boas et al. (2015) 


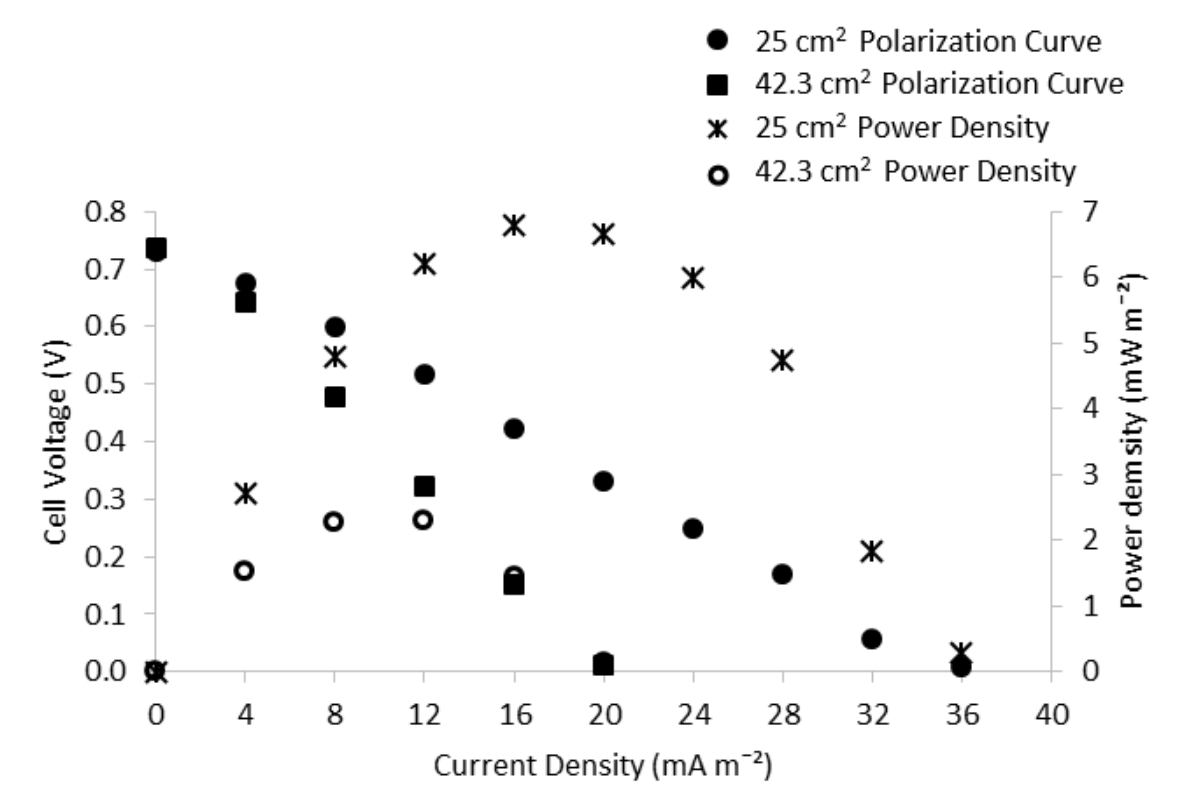

Figure 4 - Polarization and Power Density curves the two active areas tested. Operating conditions: $R e_{A}=0$, feed rate of $0.05 \mathrm{~L} \mathrm{~h}^{-1}$. Design conditions: DCMFC, Nafion 212 and anode electrode BP1".

Vilas Boas et al. (2015) 


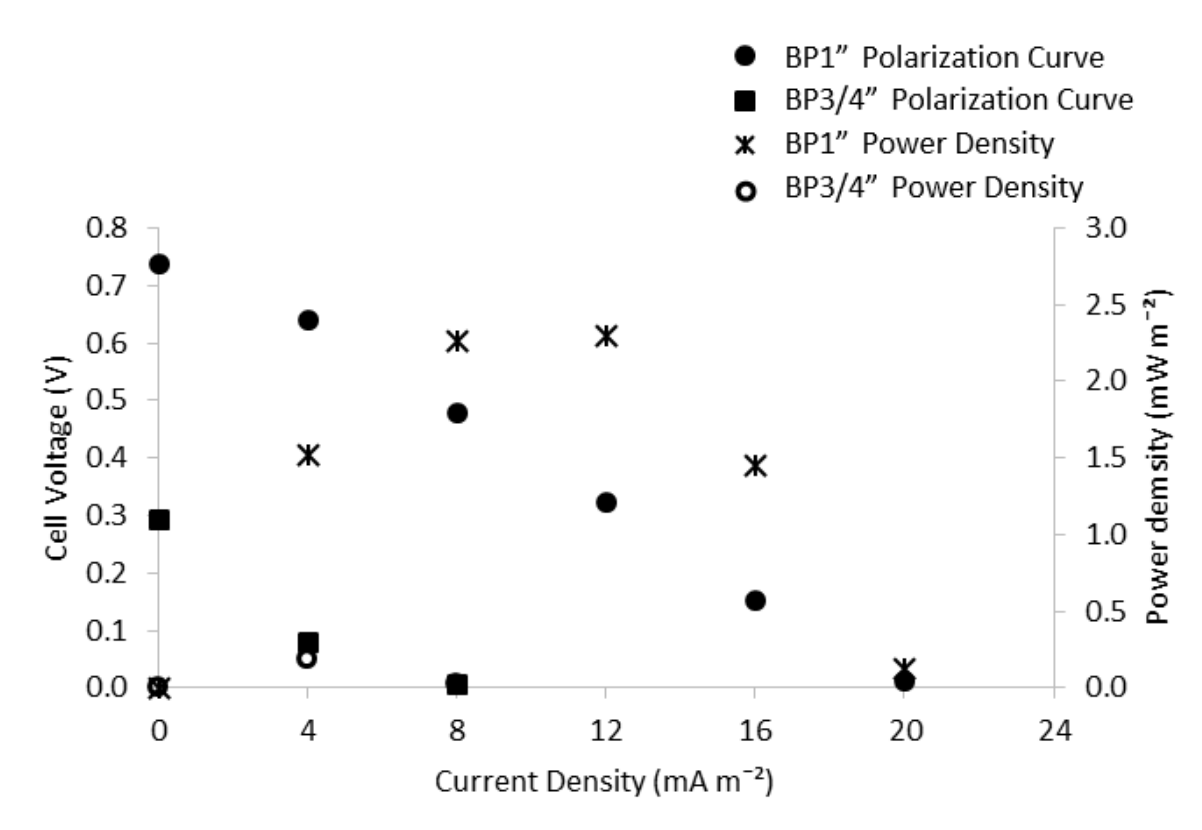

Figure 5 - Polarization and Power Density curves for the two anode electrode sizes.

Operating conditions: $R e_{A}=0$, feed rate of $0.05 \mathrm{~L} \mathrm{~h}^{-1}$. Design conditions: DCMFC, 25 $\mathrm{cm} 2$ of active area and Nafion 212.

Vilas Boas et al. (2015) 


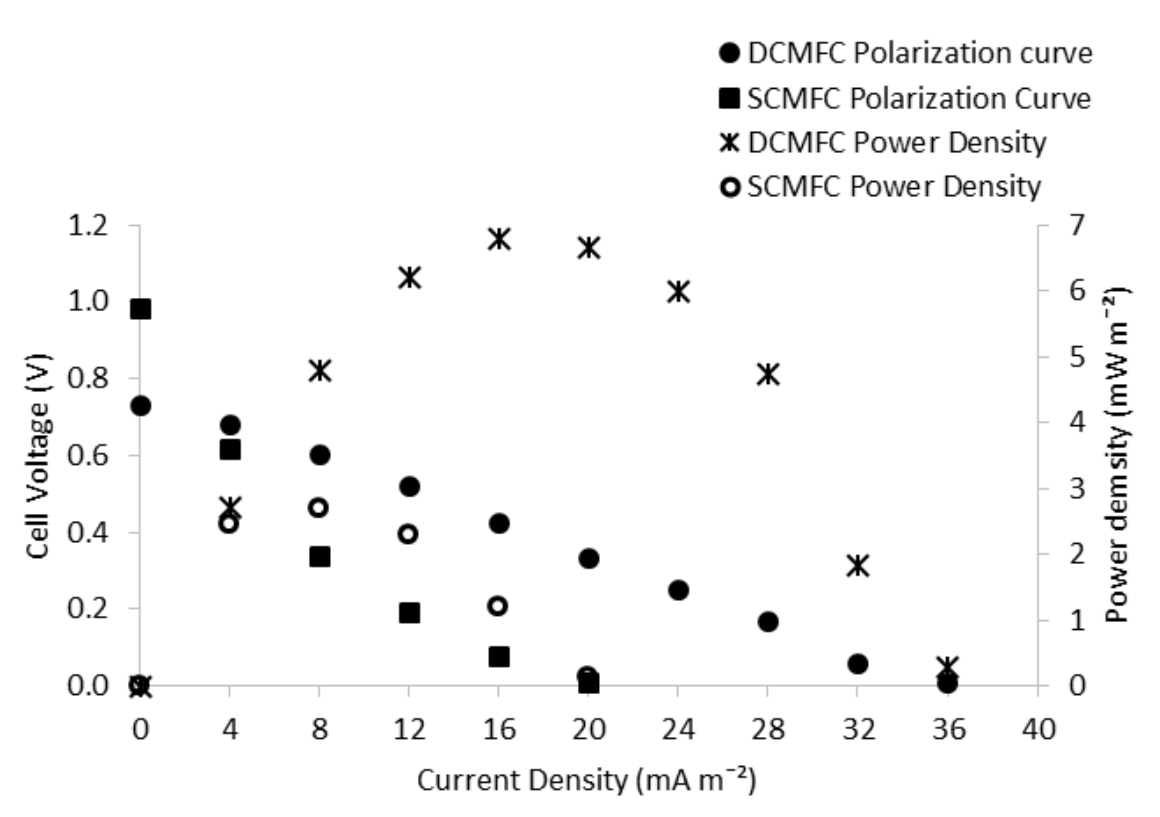

Figure 6 - Polarization and Power Density curves for the two different MFC designs. Operating conditions: $R e_{A}=0$, feed rate of $0.05 \mathrm{~L} \mathrm{~h}^{-1}$. Design conditions: $25 \mathrm{~cm}^{2}$ of active area, Nafion 212 and anode electrode BP1".

Vilas Boas et al. (2015) 
Table 1 - Maximum power density, COD removal rate and biofilm quantification for the two flow rates tested. Operating conditions: $R e_{A}=0$. Design conditions: DCMFC, $25 \mathrm{~cm}^{2}$ of active area, Nafion 212 and anode electrode BP1".

\begin{tabular}{cc|c} 
& \multicolumn{2}{c}{ Feed rate $\left(\mathrm{L} \mathrm{h}^{-1}\right)$} \\
\cline { 2 - 3 } & $\mathbf{0 . 0 5}$ & $\mathbf{0 . 1 1}$ \\
\hline \hline Maximum power density $\left(\mathrm{mW} \mathrm{m}^{-2}\right)$ & $8.09 \pm 1.52$ & $6.61 \pm 1.84$ \\
\hline Internal resistance $(\Omega)$ & 8,794 & 13,200 \\
\hline COD removal rate $(\%)$ & $57.36 \pm 11.49$ & $55.91 \pm 8.33$ \\
\hline Total polysaccharides $\left(\mu \mathrm{g} \mathrm{mg}^{-1}\right)$ & 1.87 & 4.38 \\
\hline Matrix polysaccharides $\left(\mu \mathrm{g} \mathrm{mg}^{-1}\right)$ & 1.17 & 2.46 \\
\hline Total proteins $\left.(\mu \mathrm{g} \mathrm{mg})^{-1}\right)$ & 8.31 & 5.27 \\
\hline Matrix proteins $\left(\mu \mathrm{g} \mathrm{mg}^{-1}\right)$ & 5.88 & 2.03 \\
\hline Biofilm dry weight $\left(\mathrm{mg} \mathrm{mL}^{-1}\right)$ & 0.97 & $1.10 \times 10^{6}$ \\
\hline $\mathrm{CFU} \mathrm{mL} \mathrm{mL}^{-1}$ & $5.00 \times 10^{6}$ & $5.45 \times 10^{5}$ \\
\hline \hline$\alpha\left(\mathrm{CFU} \mathrm{mg}{ }^{-1}\right)$ & $5.15 \times 10^{6}$ & \\
\hline
\end{tabular}

Vilas Boas et al. (2015) 
Table 2 - Maximum power density, COD removal rate and biofilm quantification for the two shear stress applied. Operating conditions: feed rate of $0.05 \mathrm{~L} \mathrm{~h}^{-1}$. Design conditions: DCMFC, $25 \mathrm{~cm}^{2}$ of active area, Nafion 212 and anode electrode BP1".

\begin{tabular}{cc|c} 
& \multicolumn{2}{c}{ Shear stress - $\mathrm{Re}_{\mathrm{A}}$} \\
\cline { 2 - 3 } & $\mathbf{0}$ & $\mathbf{8 3 9 7}$ \\
\hline \hline Maximum power density $\left(\mathrm{mW} \mathrm{m}^{-2}\right)$ & $8.09 \pm 1.52$ & $5.50 \pm 1.72$ \\
\hline Internal resistance $(\Omega)$ & 8,794 & 12,443 \\
\hline COD removal rate $(\%)$ & $57.36 \pm 11.49$ & $61.45 \pm 11.24$ \\
\hline Total polysaccharides $\left(\mu \mathrm{g} \mathrm{mg}^{-1}\right)$ & 1.87 & 2.87 \\
\hline Matrix polysaccharides $\left(\mu \mathrm{g} \mathrm{mg}^{-1}\right)$ & 1.17 & 1.12 \\
\hline Total proteins $\left.(\mu \mathrm{g} \mathrm{mg})^{-1}\right)$ & 8.31 & 1.85 \\
\hline Matrix proteins $\left(\mu \mathrm{g} \mathrm{mg}^{-1}\right)$ & 5.88 & 7.29 \\
\hline Biofilm dry weight $\left(\mathrm{mg} \mathrm{mL}^{-1}\right)$ & 0.97 & $3.33 \times 10^{6}$ \\
\hline $\mathrm{CFU} \mathrm{mL} \mathrm{mL}^{-1}$ & $5.00 \times 10^{6}$ & $4.57 \times 10^{5}$ \\
\hline \hline
\end{tabular}


Table 3 - Maximum power density, COD removal rate and biofilm quantification for the two active areas tested. Operating conditions: $R e_{A}=0$, feed rate of $0.05 \mathrm{~L} \mathrm{~h}^{-1}$. Design conditions: DCMFC, Nafion 212 and anode electrode BP1".

\begin{tabular}{cc|c} 
& \multicolumn{2}{c}{ Membrane area $\left(\mathrm{cm}^{2}\right)$} \\
\cline { 2 - 3 } & $\mathbf{2 5}$ & $\mathbf{4 2 . 3}$ \\
\hline Maximum power density $\left(\mathrm{mW} \mathrm{m}^{-2}\right)$ & $8.09 \pm 1.52$ & $2.58 \pm 0.34$ \\
\hline Internal resistance $(\Omega)$ & 8,794 & 16,190 \\
\hline COD removal rate $(\%)$ & $57.36 \pm 11.49$ & $59.42 \pm 6.52$ \\
\hline Total polysaccharides $\left(\mu \mathrm{g} \mathrm{mg}^{-1}\right)$ & 1.87 & 3.84 \\
\hline Matrix polysaccharides $\left(\mu \mathrm{g} \mathrm{mg}^{-1}\right)$ & 1.17 & 1.93 \\
\hline Total proteins $\left(\mu \mathrm{gg}^{-1}\right)$ & 8.31 & 12.91 \\
\hline Matrix proteins $\left(\mu \mathrm{g} \mathrm{mg}^{-1}\right)$ & 5.88 & 1.62 \\
\hline Biofilm dry weight $\left(\mathrm{mg} \mathrm{mL}^{-1}\right)$ & 0.97 & $2.43 \times 10^{6}$ \\
\hline $\mathrm{CFU} \mathrm{mL} \mathrm{mL}^{-1}$ & $5.00 \times 10^{6}$ & $1.50 \times 10^{6}$ \\
\hline$\alpha\left(\mathrm{CFU} \mathrm{mg}^{-1}\right)$ & $5.15 \times 10^{6}$ & \\
\hline \hline
\end{tabular}

Vilas Boas et al. (2015) 
Table 4 - Maximum power density, COD removal rate and biofilm quantification for the two anode electrode sizes. Operating conditions: $R e_{A}=0$, feed rate of $0.05 \mathrm{~L} \mathrm{~h}^{-1}$. Design conditions: DCMFC, $25 \mathrm{~cm}^{2}$ of active area and Nafion 212.

\begin{tabular}{cc|c} 
& \multicolumn{2}{c}{ Electrode size } \\
\cline { 2 - 3 } & BP1” & BP3/4” \\
\hline Maximum power density $\left(\mathrm{mW} \mathrm{m}^{-2}\right)$ & $2.58 \pm 0.34$ & $1.05 \pm 0.59$ \\
\hline Internal resistance $(\Omega)$ & 16,190 & 14,400 \\
\hline COD removal rate $(\%)$ & $59.42 \pm 6.52$ & $60.63 \pm 7.39$ \\
\hline Total polysaccharides $\left(\mu \mathrm{g} \mathrm{mg}^{-1}\right)$ & 3.85 & 1.31 \\
\hline Matrix polysaccharides $\left(\mu \mathrm{g} \mathrm{mg}^{-1}\right)$ & 1.94 & 0.60 \\
\hline Total proteins $\left.(\mu \mathrm{g} \mathrm{mg})^{-1}\right)$ & 12.93 & 5.60 \\
\hline Matrix proteins $\left(\mu \mathrm{g} \mathrm{mg}^{-1}\right)$ & 8.51 & 0.71 \\
\hline Biofilm dry weight $\left(\mathrm{mg} \mathrm{mL}^{-1}\right)$ & 1.62 & $3.73 \times 10^{6}$ \\
\hline $\mathrm{CFU} \mathrm{mL}{ }^{-1}$ & $2.43 \times 10^{6}$ & $5.26 \times 10^{6}$ \\
\hline \hline
\end{tabular}

Vilas Boas et al. (2015) 
Table 5 - Maximum power density, COD removal rate and biofilm quantification for the two different MFC designs. Operating conditions: $R e_{A}=0$, feed rate of $0.05 \mathrm{~L} \mathrm{~h}^{-1}$. Design conditions: $25 \mathrm{~cm}^{2}$ of active area, Nafion 212 and anode electrode BP1”.

\begin{tabular}{cc|c} 
& \multicolumn{2}{c}{ MFC design } \\
\cline { 2 - 3 } & DCMFC & SCMFC \\
\hline Maximum power density $\left(\mathrm{mW} \mathrm{m}^{-2}\right)$ & $8.09 \pm 1.52$ & $3.54 \pm 1.07$ \\
\hline Internal resistance $(\Omega)$ & 8,794 & 17,590 \\
\hline COD removal rate $(\%)$ & $57.36 \pm 11.49$ & $58.40 \pm 3.48$ \\
\hline Total polysaccharides $\left(\mu \mathrm{g} \mathrm{mg}^{-1}\right)$ & 1.87 & 3.29 \\
\hline Matrix polysaccharides $\left(\mu \mathrm{g} \mathrm{mg}^{-1}\right)$ & 1.17 & 7.26 \\
\hline Total proteins $\left.(\mu \mathrm{g} \mathrm{mg})^{-1}\right)$ & 8.31 & 4.53 \\
\hline Matrix proteins $\left(\mu \mathrm{g} \mathrm{mg}^{-1}\right)$ & 5.88 & 1.60 \\
\hline Biofilm dry weight $\left(\mathrm{mg} \mathrm{mL}^{-1}\right)$ & 0.97 & $3.97 \times 10^{6}$ \\
\hline $\mathrm{CFU} \mathrm{mL} \mathrm{mL}^{-1}$ & $5.00 \times 10^{6}$ & $2.48 \times 10^{6}$ \\
\hline \hline
\end{tabular}

Vilas Boas et al. (2015) 